\title{
FORGED GOVERNMENT CHECKS: MISALLOCATION OF LOSS BY THE FEDERAL COMMON LAW
}

Forgery of United States checks creates an annual loss of approximately two and one-half million dollars. ${ }^{1}$ Governed by the federal common law of negotiable instruments, ${ }^{2}$ risk of loss, following the chain of title in a succession

1. Government agents received for investigation 31,931 forged government checks in fiscal year 1953-54 and completed investigations of 28,837 forged checks having a value of $\$ 2,339,6 \in 0$. Sec'y TrEas. ANN. Rep. 160 (1955). In fiscal year 1954-55, 33,260 checks were received and 30,177 were investigated. The value of the checks investigated was $\$ 2,609,335.91$. SEC'x TREAS. ANN. REP. 150 (1956). The government's authority to issue checks is found in the power to contract, which is incidental to governmental sovereignty. See United States v. Tingey, 30 U.S. (5 Pet.) 115, 127-28 (1831) ; Neilson v. Lagow, 53 U.S. (12 How.) 98, 107 (1851). The United States may enter into any contract not specifically prohibited by statute or by the Constitution, whether or not the particular contract is authorized by statute. United States v. Wolper, 86 F.2d 715 (2d Cir. 1936). Congress may issue negotiable or non-negotiable commercial obligations. United States v. Janowitz, 257 U.S. 42, 45 (1921) (war savings certificates) ; Legal Tender Case, 110 U.S. 421, 444 (1884) (treasury notes); Security Nat'1 Bank v. People's Bank, 287 Mo. 464, 473, 230 S.W. $87,89-90$ (1921) (liberty bonds). Courts have never doubted that government checks were intended to be negotiable.

2. Federal common law governs the rights and duties of the government on its own checks. Clearfield Trust Co. v. United States, 318 U.S. 363 (1943) ; National Metropolitan Bank v. United States, 323 U.S. 454 (1945) ; United States v. Continental-American Bank \& Trust Co., 175 F.2d 271 (5th Cir.), cert. denied, 338 U.S. 870 (1949); Brannan, Negotiable Instruments 108 (7th ed., Beutel 1948) (hereinafter cited as Brannan); Pofcher, The Choice of Law, State or Federal, in Cases Involving Government Contracts, 12 LA. L. Rev. 37, 43 (1951) ; Comments, 53 Colum. L. Rev. 991 (1953), 30 Ore. L. Rev. 164 (1951).

Use of federal law is based on: (1) the need for uniformity in interpretation of the government's rights and duties, Clearfield Trust Co. v. United States, supra at 367; Gorrell and Weed, Erie RR: Ten Years After, 9 Oнго St. L.J. 276, 296 (1948) ; cf. United States v. Standard Oil Co., 332 U.S. 301,307 (1947) ; (2) the fact that the rights are federally created, see United States v. Independent School Dist. No. 1, 209 F.2d 578 (10th Cir. 1954) ; Comment, 40 Cornesl L.Q. 561, 577 (1955); cf. Garrett v. Moore-McCormack Co., 317 U.S. 239, 245 (1942) ; and (3) the presence of the United States as a party, Moore, Commentary on The Judicial Code 344 (1949); see United States v. County of Allegheny, 322 U.S. 174, 183 (1944). Courts have fashioned the federal common law of commercial paper from the law merchant of the Swift $\%$. Tyson era, Clearfield Trust Co. v. United States, supra at 367, and the Negotiable Instruments Law (hereinafter cited as NIL), New York, N.H. \& H.R.R. v. RFC, 180 F.2d 241, 244 (2d Cir. 1950).

Suits between private parties on government checks are governed by state law when they involve questions "essentially of local concern." Bank of America v. Parnell, 352 U.S. 29 (1956) (burden of proof), 10 VAND. L. Rev. 616 (1957), 56 CoLUMr. L. REv. 438 (1956), 1 VILLANOVA L. REv. 344 (1956). For cases reaching the same result without considering the choice of law problem, see Oquendo v. Federal Reserve Bank, 98 F.2d 708 (2d Cir.), icrt. desticd, 305 U.S. 656 (1938) (authority to endorse); Mclfurray v. Rhode Island, Inc., 117 A.2d 114 (D.C. Munic. Ct. 1955) (same); McCollum v. Graber, 207 Ark. 1053, 184 S.W.2d 264 (1944) (status as holder in due course) ; Bryant v. McGowan, $151 \mathrm{~Pa}$. Super. 529, 30 A.2d 667 (1943) (status of payee). But even in a suit between private litigants, federal law determines issues on the nature of the rights and obligations created 
of lawsuits, may temporarily rest on a number of parties. But the ultimate risk will fall on the party who must pursue his remedy against the forger. ${ }^{3}$ Both drawer and drawee of its own checks, the government, as drawee, will bring the first suit to recover payment from the party, ordinarily a bank, that presented the forged check. ${ }^{4}$ And the resolution of this action determines where the ultimate risk of loss will lie. If the government is successful, the presenting bank will sue its predecessor in the chain of title, and the ultimate risk will be borne by the original taker from the forger. ${ }^{5}$ Should the initial action fail, the

by the government paper itself, Bank of America v. Parnell, stlpra at 34 (whether government bonds were overdue), and those involving a "federal interest" in uniformity of interpretation, United States v. Dauphin Deposit Trust Co., 50 F. Supp. 73 (M.D. Pa. 1943) (transferability of United States savings bonds); Stephens v. First Nat'1 Bank, 65 Nev. 352, 196 P.2d 756 (1948) (same). Federal law will be used to achieve uniformity even though contrary to state policy. Succession of Tanner, 24 So.2d 642 (La. 1946); Ervin v. Conn, 225 N.C. 267, 34 S.E.2d 402 (1945) ; Jones, United States Savings Bonds, Series E, $F$ and $G, 11$ MD. L. REv. 265 (1950). The tenuous distinctions drawn in the few reported decisions make it difficult to predict which issues involved in private suits will be subject to federal law. For a discussion of the choice of law problem in allied fields, ste Notes, 105 U. PA. L. Rev. 266 (1956) (Farmers Home Administration Act), 55 Colum. L. REv. 574 (1955) (Veteran' Emergency Housing Act).

Private notes or checks, however, remain subject to state law even though the United States is a party. United States v. Hansett, 120 F.2d 121, 122 (2d Cir. 1941); United States v. Skinner, 137 F. Supp. 234 (D. Idaho 1956); United States v. Klatt, 135 F. Supp. 648 (S.D. Cal. 1955).

3. Suit against the forger is an unsatisfactory remedy since he may have left the jurisdiction, have no funds or have "been hanged." See Price v. Neal, 3 Eurr. 1355, 97 Enq. Rep. 871 (K.B. 1762) ; Moore, Forgery by Employees, 3 The Practical LaWyer No. 1, pp. $60,69-70$ (Jan. 1957).

4. Normally, a government agency, as drawer, will draw a check on the Treasury Department, as drawee. The fact that the government is both drawer and drawee of its checks eliminates one step in the procedural chain of recovery through which losses from forged checks are allocated. In private law, the drawer sues the drawee for charging his account with a forged check. BRITTON, BrLLs AND Notes $\$ 132$ (1943) (hereinafter cited as Britton). And the drawee, if liable, has an action against the party who presented the check to it. Comment, 62 YALE L.J. 417, 418 (1953). But the government, as drawerdrawee, sues a presenting bank directly.

Where the United States has funds in a private bank, it is treated like any other drawer. England Nat'1 Bank v. United States, 282 Fed. 121 (8th Cir. 1922); United States v. National Exchange Bank, 45 Fed. 163 (C.C.E.D. Wis. 1891). Upon receiving cancelled checks from a drawee bank, the government has a duty to examine them within a reasonable time to determine whether the drawee has charged any forged or altered checks to its account. England Nat'1 Bank v. United States, supra at 126-27. And failure to make this examination within a reasonable time, or to notify the drawee without delay upon discovery of a defective check, is deemed a conclusive admission of the account's correctness. Ibid; Leather Manufacturers' Bank v. Morgan, 117 U.S. 96 (1886) ; Comment, 6 ARK. L. Rev. 199 (1952). See, generally, Arant, Forged Checks-The Duty of the Depositor to His Bank, 31 YALE L.J. 598 (1922); White, In Re: Liability of Bank for Payment of Forged or Unauthorized Checks, 17 INs. Counsel J. 162 (1950).

5. See BRITTON \$ 139 .

Whether or not the government is successful, it will still be liable to the payee on the underlying obligation. See Rettinghouse v. Krey Packing Co., 200 S.W.2d 584 (Mo. App. 1947) (payee against drawer on underlying obligation); Shepard and Morse Lumber 
government will bear the risk of loss, suit against the forger becoming its sole possibility for relief." Although the courts have not been influenced by the general volume of federal check transactions to favor the government in any given suit, they have also failed to consider its natural capacity for risk distribution as a basis for denying recovery. ${ }^{7}$ Rather, losses have been allocated under traditional doctrine which determines liability according to the type of forgery involved. Occasionally, the risk of loss so imposed is actually based on negligence; more often, the result can be attributed only to mechanical application of the doctrine.

When its signature as drawer is forged, the government bears the ultimate risk of loss. Under the "final payment rule," it cannot recover sums expended in cashing such a check from a good faith presenting bank. ${ }^{8}$ As drawee, the

Co. v. Eldridge, 171 Mass. 516, 51 N.E. 9 (1898) (dictum) (same); Blacker and Shepard Co. v. Granite Trust Co., 284 Mass. 9, 187 N.E. 53 (1933) (payee against drawee for conversion); A. Paul Goodall Real Estate \& Ins. Co. v. North Birmingham Am. Bank, 225 Ala. 507, 144 So. 7 (1932) (payee against drawee for money had and received). See, generally, Kessler, Ievi \& Ferguson, Some Aspects of Payment by Negotiable Instruments: A Comparative Study, 45 Yale L.J. 1373 (1936).

6. Comment, 62 Y YLE L.J. 417 (1953).

7. "[G] reat business houses are held to... [ the same] responsibility ... [as] small ones. The United States does business on business terms ... [and] is not excepted from the general rule[s] [of negotiable instruments] by the largeness of its dealings and its having to employ agents to do what if done by a principal in person would leave no room for doubt." United States v. National Exchange Bank, 270 U.S. 527, 534-35 (1926). When the government becomes a party to commercial paper, it yields its position of sovereignty and enters the domain of commerce where it enjoys the same rights and suffers the same responsibilities as private persons. See, e.g., The Floyd Acceptances, 74 U.S. (7 Wall.) 666, 675 (1869) ; Cooke v. United States, 91 U.S. 389, 398 (1875); United States v. Guaranty Trust Co., 293 U.S. 340,350 (1934). See, generally, Wachtell, Sozercign Immunity and Its Application to Commercial Paper, 6 BRookLYN L. Rev. 1 (1936) ; Dezclopments in the Law-Remedies Against The United States and Its Officials, 70 HARv. L. REv. 827, 884 (1957). The United States would probably have to subject itself to the usual rules of commercial paper in any event or parties would be reluctant to accept government checks. See, c.g., Finley v. United States, 130 F. Supp. 788 (D.N.J. 1955).

Congress has removed the usual sovereign immunity from suit in the area of government check transactions. See the Tucker Act, 28 U.S.C. $\$ 1491$ (4) (1952), mäking the government amenable to suit on express and implied contracts.

No case has been found in which the court has considered risk-distribution as a basis of government liability.

8. United States v. Chase Nat'l Bank, 252 U.S. 485 (1920); Bank of United States v. Eank of Georgia, 23 U.S. (10 Wheat.) 333 (1825). See Britron $\$$ 133, 135-36; Aigler, The Doctrine of Price v. Neal, 24 MrcH. L. Rev. 809 (1926); Note, 2 U. Cinn. L. REv. 299 (1928).

Negligence of a party in receiving a forged check will make it liable to the government. See United States v. Chase Nat'l Bank, supra at 495-96 (dictum); Comment, 43 ILl. L. REv. 823 (1949).

The federal courts have refused to extend the final payment rule to postal money orders. Bolognesi v. United States, 189 Fed. 335 (2d Cir. 1911); United States v. Northwestern Nat'1 Bank \& Trust Co., 35 F. Supp. 484 (D. Minn. 1940). But see United States v. Citizens and So. Nat'l Bank, 144 F. Supp. 601 (S.D. Ga. 1956). 
government is held to knowledge of the drawer signatures of authorizerl agents. ${ }^{9}$ Paying a check bearing a forged signature thus becomes negligence estopping the government from relying on the forgery in a suit against the bank. "1" Similar reasoning is used to defeat claims for overpayment of a raised check. Since the government "knows" the amount of its checks, payment estops it from later questioning the face value. ${ }^{11}$

On the other hand, paying a check bearing a forged endorsement does not automatically preclude recovery by the government. ${ }^{12}$ In presenting this type of forged check for payment, a bank impliedly warrants its title. ${ }^{13}$ But since a forged endorsement does not convey title, this warranty is breached. In addition, the defect in title constitutes a lack of consideration which, voiding the transaction, enables the government to recover for money had and received. $^{14}$ Moreover, modern Treasury regulations furnish an additional remedy by requiring an express guaranty of prior endorsements on presentation of a government check. ${ }^{15}$ This guaranty warrants all prior endorsements

9. United States v. Chase Nat'1 Bank, supra note 8, at 496; United States v. Bank of New York, 219 Fed. 648, 650 (2d Cir. 1914).

10. Cooke v. United States, 91 U.S. 389, 397 (1875) (dictum).

11. United States v. National Exchange Bank, 270 U.S. 527 (1926), 26 Colur. L. Rev. 1030 (1926), 11 MinN. L. Rev. 68 (1926) ; Wells Fargo \& Co. v. United States, 45 Fed. 337 (C.C.N.D. Cal. 1891) (dictum). Generally, a drawee is not charged with knowledge of the amount of a drawer's checks. BRIrToN $\$ 140$. Consequently, a drawee can recover the amount that a check has been altered, even from a good faith purchaser. Woodward, The Risk of Forgery or Alteration of Negotiable Instruments, 24 Coluns. L. REv. 469, 474 (1924). But the United States, since it is both drawer and drawee, is considered similar to a maker paying his own altered note. See 35 Y ALE L.J. 1009, 1010 (1926).

12. The majority of forged government checks bear forged endorsements. See SEc'Y Treas. AnN. Rep. 113 (1956).

13. United States v. National Exchange Bank, 214 U.S. 302, 319 (1909).

14. Id. at 316; Leather Manufacturers' Bank v. Merchants' Bank, 128 U.S. 26, 35 (1888) ; Ladd \& Tilton Bank v. United States, 30 F.2d 334, 337 (9th Cir. 1929); United States v. National Bank of Republic, 141 Fed. 208, 209 (C.C.D. Mass. 1902); United States v. Story, 34 F. Supp. 571 (M.D. Tenn. 1940).

15. 31 C.F.R. § 202.25(c) (1949).

At common law, a drawee who paid a check bearing a forged endorsement could not recover the amount of the check from an agent presenting bank which had remitted the proceeds to its principal. United States v. American Exchange Nat'l Bank, 70 Fed. 232 (S.D.N.Y. 1895); WoODWARD, QUASI ConTRACTs $\$ 27$ (1913). The express guaranty of prior endorsements made a presenting bank liable to the drawee, regardless of such remission. Philadelphia Nat'l Bank v. Fulton Nat'l Bank, 25 F.2d 995 (N.D. Ga. 1928); 20 ORE. L. REv. 80 (1940).

If a government check is drawn payable to the drawer himself, the guaranty includes the drawer's endorsement. 31 C.F.R. $\$ \$ 202.25$ (c), 202.27 (1949). This could be interpreted to restrict the final payment rule, see text at notes 8-11, where a party forges a drawer's signature and makes the check payable to that drawer. An endorsement of the drawer's name by the defrauding party is a forgery. Hence, the government could sue a presenting bank for breach of its guaranty of the drawer's endorsement. Absent an express overruling of the final payment doctrine, however, the regulation should apply only to cases involving a valid drawer's signature. Even if the regulation was not intended to be so 
effective to give the holder legal title and the coincident right to enforce payment. ${ }^{10}$ Since a forged endorsement cannot convey these rights, presenting the check for payment also breaches the express guaranty. ${ }^{17}$

The government's right to sue the presenting bank for breach of express guaranty or implied warranty is restricted by a statute of limitations and the operation of laches. The period of limitation expires six years after accrual of the government's cause of action. ${ }^{18}$ Since the guaranties of prior endorsements and title are breached when the check is cashed, and the right to sue is not dependent on notice or demand, the cause of action is complete at the date of payment. ${ }^{10}$ Within the limitation period, prompt discovery of a forgery is

limited, the guaranty should have no effect since forgery of the drawer's signature makes the check wholly inoperative. See United States v. Chase Nat'1 Bank, 252 U.S. 485, 495-96 (1920) (government denied recovery where both drawer's and payee's signatures forged and names were the same); NIL $\S 23$.

16. United States v. Guaranty Trust Co., 293 U.S. 340,349 (1934). The guaranty does not extend to warranting a payee's legal status, such as widowhood, which is a condition precedent to the payee's receiving a check from the government. United States v. Peoples-Pittsburgh Trust Co., 34 F. Supp. 230 (W.D. Pa. 1940), 7 U. PItr. L. REv. 51 (1940) ; United States v. Liberty Ins. Bank, 26 F.2d 493 (W.D. Ky. 1928). Nevertheless, the government can recover money paid to a holder who knows that the payee is not entitled to the check because of a change in status. United States v. Michaelson, 58 F. Supp. 796 (D, Minn. 1945).

17. National Metropolitan Bank v. United States, 323 U.S. 454 (1945); Clearfield Trust Co. v. United States, 318 U.S. 363 (1943).

For a general discussion of the actions for breach of implied warranty and express guaranty, see Britron § 139; Dahlin, What Bankers Should Know About Forged Endorsements, 73 Banking L.J. 394 (1956); Corker, Risk of Loss from Forged Endorsements, 4 Stan. L. Rev. 24 (1951); Kessler, Forged Indorsements, 47 Yale L.J. 863 (1938) ; Note, 22 U. CiN. L. REv. 219 (1953).

18. 60 STAT. 31 (1946), 31 U.S.C. $\$ 129$ (1952). "The general purpose of this legislation is to provide relief for banks, merchants, and others handling Government checks by limiting the time within which the Government may bring action to recover the proceeds of such checks by reason of a forged endorsement or unauthorized signature." H.R. REp. No. 101, 79th Cong., 1st Sess. 2 (1945). The statute of limitations has been interpreted to have retroactive effect. United States v. Union Planters Nat'l Bank \& Trust Co., 175 F.2d 684 (5th Cir. 1949).

If a party liable for presenting a forged check fraudulently conceals the cause of action from the United States, a suit by the government may be brought within two years after the discovery of such cause of action. 60 STAT. 31 (1946), 31 U.S.C. $\$ 131$ (1952).

When the government becomes the holder of a private note or check, it is considered acting in a "sovereign capacity" and thus exempt from the operation of laches or any statute of limitations. United States v. Thompson, 98 U.S. 486 (1878); Person v. United States, 112 F.2d 1 (Sth Cir. 1940); United States v. Thomas, 107 F.2d 765 (5th Cir. 1939). However, transfer of a commercial instrument, on which the statute of limitations has already run, to the United States will not give the government an enforceable claim. See Guaranty Trust Co. v. United States, 304 U.S. 126 (1938) ; United States v. Buford, 28 U.S. (3 Pet.) 12, 29-30 (1830).

19. Clearfield Trust Co. v. United States, 318 U.S. 363, 368 (1943) ; Leather Manufacturers' Bank v. Merchants' Bank, 128 U.S. 26 (1888); United States v. City Sav. Bank \& Trust Co., 73 F.2d 486, 487 (6th Cir. 1934); United States v. National Bank of Republic, 141 Fed. 208, 209 (C.C.D. Mass. 1902). See also Note, Application of Statute of Limitations to Forged Indorsements in Check Collection Cases, 47 Y ALE L.J. 827 (1938). 
not a condition precedent to suit by the government. ${ }^{20}$ Once a forgery has been discovered, however, failure to give prompt notice to a presenting bank may operate as laches. ${ }^{21}$ Thus recovery by the government will be barred where the delay in notice causes damage-loss of recourse against prior endorsers-to the presenting bank. ${ }^{22}$

Moreover, timely suit may fail under the "impostor rule," which prevents recovery when the government itself created the risk of loss. Inducing the government to issue him a check by misrepresenting his identity, an impostor acquires legal title. ${ }^{23}$ His subsequent endorsement in the assumed name is not a forgery, since the government intended to make the check payable to him. ${ }^{24}$ So expressed, the impostor rule precludes the government's recovery against the presenting bank. ${ }^{25}$ For the latter warranted the check was properly en-

20. National Metropolitan Bank v. United States, 323 U.S. 454, 457 (1945), 7 GA. B.J. 483.

21. Ladd \& Tilton Bank v. United States, 30 F.2d 334 (9th Cir. 1929) (delay of nineteen months); United States v. Clinton Nat'l Bank, 28 Fed. 357 (C.C.S.D. Iowa 1886) (ten years); United States v. National Rockland Bank, 35 F. Supp. 912 (D. Mass. 1940) (ten years); United States v. National City Bank, 28 F. Supp. 144 (S.D.N.Y. 1939) (three and one-half years); United States v. Citizens Union Nat'l Bank, $40 \mathrm{~F}$. Supp. 609 (W.D. Ky. 1941) (five years, state law applied). See Notes, 15 GA. B.J. 243 (1952), 10 N.Y.U. Intra. L. REv. 263 (1955).

22. United States v. National Rockland Bank, supra note 21 (bankruptcy of prior parties); United States v. National City Bank, sulpra note 21 (same). But see Fulton Nat'1 Bank v. United States, 197 F.2d 763 (5th Cir. 1952) (running of state statute of limitations), 37 MrNw. L. Rev. 201 (1953).

Mere delay, without any damage to a party, will not operate as laches against the government. Clearfield Trust Co. v. United States, 318 U.S. 363, 369 (1943); United States v. National Exchange Bank, 141 Fed. 209 (C.C.D. Mass. 1905) ; United States v. National Park Bank, 6 Fed. 852 (S.D.N.Y. 1881). See Note, 55 Colum. L. Rev. 1177, 1181-82 (1955).

23. See United States v. Continental-American Bank \& Trust Co., 175 F.2d 271 (5th Cir.), cert. denied, 338 U.S. 870 (1949).

24. United States v. Continental-American Bank \& Trust Co., 161 F.2d 935, 936 (5th Cir. 1947) retrial, 79 F. Supp. 450 (W.D. La. 1948), aff'd, 175 F.2d 271 (5th Cir.), cert. denied, 338 U.S. 870 (1949) ; United States v. First Nat'1 Bank \& Trust Co., 92 F. Supp. 356, 358 (W.D.N.C. 1950). United States v. Bank of North Wilkesboro, 183 Fed. 759, 760 (4th Cir. 1910); United States v. National Exchange Bank, 45 Fed. 163, 166 (C.C.E.D. Wis. 1891).

The government has argued that a disbursing agent has no authority to issue a check to other than a real beneficiary and, therefore, cannot intend to make a check payable to an impostor. See, e.g., United States v. First Nat'l Bank, 131 F.2d 985, 989 (10th Cir. 1942), cert. denied, 318 U.S. 774 (1943). But the courts have refused to assume that the agent could not have intended to give a check to the impostor merely because he had no legal authority to do so. Instead, they derive the requisite intent from the physical transfer of the instrument. United States v. Continental-American Bank \& Trust Co., supra at 937; United States v. First Nat'l Bank, stipra at 989.

25. United States v. Continental-American Bank \& Trust Co., 79 F. Supp. 450, 454 (W.D. La. 1948), aff'd 175 F.2d 271 (5th Cir.), cert. denied, 338 U.S. $\$ 70$ (1949), 21 So. CALIF. L. Rev. 280 (1948), 34 V. L. Rev. 85 (1948) ; United States v. First Nat'l Bank, supra note 24, 41 Mich. L. Rev. 1195; United States v. National Exchange Bank, supra note 24 . In a few early cases the courts refused to apply the impostor rule. See Onondaga 
dorsed, not honestly obtained. ${ }^{26}$ The government's negligence in allowing the impostor's fraud is thus employed to defeat its claim. ${ }^{27}$ If the presenting bank failed to exercise reasonable care in receiving a check from an impostor or negligently contributed to his fraud, however, the government will be allowed to recover. ${ }^{28}$ Liability under the impostor rule gives way to the negligence of the bank which is deemed to have caused the risk of loss. ${ }^{29}$

Often, the government's negligence has not been recognized in cases seemingly within the scope of the impostor rule. Where a check payable to a named payee is erroneously delivered to another person with the same or similar name, the impostor rule does not bar recovery by the government. ${ }^{30}$ And the

County Sav. Bank v. United States, 64 Fed. 703, 705 (2d Cir. 1894); United States v. Canal Bank \& Trust Co., 29 F. Supp. 605 (E.D. La. 1939) ; United States v. National City Bank, 28 F. Supp. 144 (S.D.N.Y. 1939).

Usually the impostor fraudulently obtains a certificate, such as an Adjusted Service Certificate, which entitles the beneficiary designated therein to a government check. He then represents himself as the beneficiary to a government agency. On the basis of the certificate, and a possible notarized statement that he is the beneficiary, the agency will issue a check to him. See, e.g., United States v. Continental-American Bank \& Trust Co., 79 F. Supp. 450 (W.D. La. 1948), aff'd, 175 F.2d 271 (5th Cir.), cert. denied, 338 U.S. 870 (1949). For general discussion of the impostor rule, see Abel, The Imposter Payee: Or, Rhode Island Was Right, 1940 WIs. L. Rev. 161, 362; Witherspoon, What is The Imposter Rule?, 51 Conr. L.J. 137 (1946) ; Notes, 3 U. Fla. L. Rev. 129 (1950), 36 Gro. L.J. 427 (1948), 7 BrcokLyN L. Rev. 220 (1937).

26. United States v. First Nat'1 Bank \& Trust Co., 92 F. Supp. 356, 359 (W.D.N.C. 1950); United States v. Continental-American Bank \& Trust Co., supra note 25, at 454.

27. The government is under a duty to ascertain the party entitled to a government check. United States v. National Exchange Bank, 45 Fed. 163, 166-67 (C.C.E.D. Wis. 1891). Delivering a check to an unentitled person is negligence which is deemed the cause of any loss. Id. at 167; United States v. First Nat'1 Bank \& Trust Co., 17 F. Supp. 611, 613-14 (W.D. Okla. 1936). Moreover, a government agency expects a party to pay a check on the same identification and proofs which induced the agency to issue the check. United States v. First Nat'l Bank, 131 F.2d 985, 989 (10th Cir. 1942), cert. denied, 318 U.S. 774 (1943). A bank relying on these means of identification in cashing an "impostor" check exercises reasonable care and is thereby relieved from liability. United States v. First Nat'l Bank \& Trust Co., 92 F. Supp. 356, 359 (W.D.N.C. 1950).

For a negligence approach to the imposter rule in state law, see, e.g., Santa Maria v. Industrial City Bank and Banking Co., 326 Mass. 440, 95 N.E.2d 176 (1950); Comment, 62 YALE L.J. 417, 427-28 (1953).

28. Fulton Nat'l Bank v. United States, 107 F.2d 86 (5th Cir. 1939) (failure to exercise reasonable care in identifying intended payee); United States v. Michaelson, 58 F. Supp. 796 (D. Minn. 1945) (party should have known impostor not entitled to check); United States v. First Nat'l Bank, 124 F.2d 485 (10th Cir. 1941) (bank certified that impostor was person he pretended to be).

29. United States v. First Nat'1 Bank, 124 F.2d 484, 488 (10th Cir. 1941).

30. Fulton Nat'l Bank v. United States, 197 F.2d 763, 764 (5th Cir. 1952); United States v. National City Bank, 28 F. Supp. 144, 149-50 (S.D.N.Y. 1939) (dictum). Cf. the minority state rule that mailing a check to a wrong party with the same name as the intended payee constitutes sufficient negligence to make the drawer bear the risk of loss. Keck v. Browne, 314 Ky. 151, 234 S.W.2d 183 (1950), 39 Kx. L.J. 476 (1951) ; S. Weisberger Co. v. Barberton Sav. Co., 84 Ohio St. 21, 95 N.E. 379 (1911); Britron $\$ 152$. 
government has been allowed recovery for paying a check issued to an impostor but endorsed in the assumed name by another party. ${ }^{31}$ Although the endorsement in each of these cases is a forgery, and the results could thus be explained in terms of defective title, the courts have still overlooked the government's negligence in delivering and issuing such checks. ${ }^{32}$

Further, the "fictitious payee rule," regularly utilized to allocate private forgery losses on the basis of negligence, has been rejected by the federal courts. When an employee fraudulently draws checks to non-existent payees and endorses them to his own use, his employer bears the risk of loss under the Negotiable Instruments Law. ${ }^{33}$ A check payable to a fictitious payee is considered bearer paper so that title passes by delivery. ${ }^{34}$ Thus the employee's

31. United States v. Union Trust Co., 139 F. Supp. 819, 822 (D. Md. 1956) (dictum) (listing of exceptions to impostor rule). Some state courts have reached a contrary conclusion. See, e.g., Russell v. Second Nat'1 Bank, 136 N.J.L. 270, 55 A.2d 211 (Ct. Err. \& App. 1947).

32. Fulton Nat'1 Bank v. United States, 197 F.2d 763, 764 (5th Cir. 1952).

33. Bartlett v. First Nat'l Bank, 247 I1l. 490, 93 N.E. 337 (1910); Snyder v. Corn Exchange Nat'1 Bank, 221 Pa. 599, 70 Atl. 876 (1908). See, generally, Britron $§ 149$; Maurice, Check Forgery Claims-Fictitions Payees and Imposters, 1944 Iss. L.J. 201; Thayer, Fictitions Payees in Bills of Exchange: A Comparative Study, $25 \mathrm{Kr}$. L.J. 203 (1937) ; Comment, 18 U. CHI. L. Rev. 281 (1951).

The NIL is in effect in every state of the union, with the exception of Pennsylvania which recently repealed the act and adopted the Uniform Commercial Code. 5 UNIForar Laws ANn. 6 (Supp. 1956). It is the only uniform law which has received unanimous state adoption. Horack, The Future of Uniform Laws-The Commercial Code, 9 Orro ST. L.J. 555 (1948). However, the effectiveness of the NIL's attempt to establish a truly national body of law has been questioned. Steffen, Statutory Material For Cases on Commerctal and Investarent Paper vi-viii (2d ed. 1954). Judicial interpretation and amendments by state legislatures have resulted in conflicting doctrines. Id. at vi. Moreover, the NIL does not cover the entire field of commercial paper. NIL $\$ 196$. And in this area, where the law merchant governs, divergencies among states are frequent. See Brannan 72 (confusion in the law merchant).

For discussion of problems of loss allocation under state law see, e.g., BRITToN, §§ 133152; BranNan 437-80; Corker, Risk of Loss from Forged Indorsements, 4 STAN. L. REv. 24 (1951) ; Kessler, Forged Indorsements, 47 Y ArE L.J. 863 (1938); Woodward, The Risk of Forgery or Alteration of Negotiable Instruments, 24 Colum. L. Rev. 469 (1924) ; Comment, Allocation of Losses from Check Forgeries Under The Law of Negotiable Instruments and The Uniform Commercial Code, 62 YaLe L.J. 417 (1953) ; Comment, 22 U. CIN. L. REv. 219 (1953).

34. American Hominy Co. v. National Bank, 294 Ill. 223, 128 N.E. 391 (1920); Wueller \& Martin Co. v. Liberty Ins. Bank, 187 Ky. 44, 218 S.W. 465 (1920) ; NIL $\S \S 9(3), 30$.

The main problem has been the determination of when a check is payable to a fictitious payee. Note, 2 DRAKE L. REv. 70 (1952). NIL § 9(3) provides: "The instrument is payable to bearer:... (3) when it is payable to the order of a fictitious or non-existing person, and such fact was known to the person making it so payable." The phrase "the person making it so payable" has been interpreted to mean the party who actually drew the check. Kulp, The Fictitions Payee, 18 Mrcr. L. Rev. 296, 304 (1919). Therefore, a check will be payable to bearer only if the fraudulent employee himself signs the check with the intent that it be payable to a non-existent party. See cases collected in BranNaN 324. But negligence in not discovering the fraud of his employee may bar the employer 
forged, but unnecessary, endorsement does not defeat the title of any subsequent holder. ${ }^{35}$ In addition, by amendment to the NIL, many states apply the fictitious payee rule to cases where one employee fraudulently makes out the checks but another signs as drawer, ${ }^{36}$ and where the defrauding employee induces the drawer to issue checks to non-existent payees by supplying a voucher. ${ }^{37}$ Yet, when a government employee fraudulently prepares a series of checks payable to fictitious payees, and some other employee signs as drawer, the latter's intent to make the checks payable to existing persons controls. ${ }^{38}$ Consequently, the paper is considered payable to order and title will pass only by genuine endorsement. ${ }^{39}$ Because a forgery is not a genuine endorsement, the risk of loss will fall on the party who took the check from the defrauding employee. ${ }^{40}$ And, in the one case in which a government employee himself fraudulently signed as drawer, the court held the government, not the em-

from recovery. Id. at 323-24. And statutory amendment in many states has extended the rule to other cases where the fraudulent employee does not sign the check. See text at notes 36-37 infra.

35. Southall v. Columbia Nat'l Bank, 244 S.W.2d 577, 580 (Mo. App. 1951) ; Prugh, Combest \& Land, Inc. v. Linwood State Bank, 241 S.W.2d 83, 87 (Mo. App. 1951). Since a check payable to bearer is negotiated by delivery, no endorsement is necessary to pass title. See NIL $\$ 30$.

36. Houghton Mifflin Co. v. Continental I11. Nat'l Bank and Trust Co., 293 I11. App. 423,12 N.E.2d 714 (1938).

37. Hillman v. Kropp Forge Co., 340 Ill. App. 606, 92 N.E.2d 537 (1950) ; Cítizens Loan \& Security Co. v. Trust Co., 79 Ga. App. 184, 53 S.E.2d 179 (1949). The amendment provides: ". . the instrument is payable to bearer ... (3) when it is payable to the order of a fictitious or non-existing ... person ... and such fact was known to the person making it so payable or knozon to his employee or ather agent who supplies the name of such payec." NIL $\$ 9(3)$, as amended. (Emphasis added.) It has been adopted in twenty states. See 5 Uniform Laws Ann. 24-25 (Supp. 1956); see also Boardman, Proper Construction of The So-Called "Bankers' Amendment" to Section 9(3) of the Negotiable Instrunents Act and Its Significance Respecting Forgery Clains Under Bankers" Blanket Bands, 17 Ins. Counsel J. 166 (1950).

38. See National Metropolitan Bank v. United States, 323 U.S. 454 (1945), 31 VA. L. Rev. 683 (1945) ; Washington Loan \& Trust Co. v. United States, 134 F.2d 59 (D.C. Cir. 1943), 31 GEo. L.J. 487; Farmers' State Bank v. United States, 62 F.2d 178 (5th Cir. 1932). The subject situation would not ordinarily be covered by the fictitious payee rule. See note 34 supra. However, the government would bear the ultimate risk of loss if the court found the government negligent or NIL $\S 9(3)$ as amended incorporated in the federal common law. Ibid. The government has once been held liable in a similar situation on the basis of the policy of $\S 9(3)$, even though the amended section was not part of the state law which the court ostensibly applied. United States v. Bank of America Nat'1 Trust \& Sav. Ass'n 47 F. Supp. 279 (N.D. Cal. 1942). A new trial was granted because of the mandate of Clearfield Trust Co. v. United States, 318 U.S. 363 (1943), see note 2 supra, to apply federal law. United States v. Bank of America Nat'l Trust \& Sav. Ass'n, 51 F. Supp. 751 (N.D. Cal. 1943). The final disposition of the case was not reported.

39. Washington Loan \& Trust Co. v. United States, 134 F.2d 59 (D.C. Cir. 1943) ; NIL $\$ 30$.

40. See note 5 supra and accompanying text. 
ployee, drawer of the check. ${ }^{41}$ Since defrauding the government was clearly beyond the scope of the employee's authority, neither his knowledge that the payee was fictitious nor his intent to make the check so payable was imputed to the government, which itself would not intend to draw a check to a nonexistent person..$^{2}$ Accordingly, the court held the check to be order, not bearer, paper, thus enabling the government to recover. ${ }^{43}$ A contrary holding would have required treating the employee as drawer. In refusing to do so, the court departed from the established pattern of state law without explanation. ${ }^{44}$ The fictitious payee rule was thus rejected.

But allowing the government to recover in fictitious payee situations requires disregard of its negligence. Proper examination and supervision by government officials could reduce the loss caused by the actions of fraudulent employees through restricting their opportunities for obtaining fictitious payee checks. ${ }^{45}$ Yet the presenting bank which has expressly guaranteed prior endorsements cannot raise want of care on the part of government officials as a defense. ${ }^{46}$ Their negligence is deemed insufficient to overcome the bank's

41. United States v. National Bank of Commerce, 205 Fed. 433 (9th Cir. 1913), judgement aff'd on new opinion, 224 Fed. 679 (9th Cir. 1915), cert. denied, 241 U.S. 658 (1916); Britton 700-702 \& n.3; Brannan 330.

42. United States v. National Bank of Commerce, 205 Fed. 433, 438 (9th Cir. 1913). As a general rule, the government is bound on its checks only when they are drawn by authorized agents. The Floyd Acceptances, 74 U.S. (7 Wall.) 666 (1868); Hooc v. United States, 218 U.S. 322 (1910) ; United States v. Jones, 176 F.2d 278 (9th Cir. 1949) ; StreEt, Governmental Lrability, A Comparative Study 84 (1953); MeIntire, Authority of Government Contracting Officers: Estoppel and Apparent Authority, 25 Geo. Wask. L. REv. 162 (1957).

Treasury circulars, requiring that checks drawn by government disbursing officers be in favor of a named party, have been interpreted as denying such officers power to issue checks payable to fictitious payees. National Bank of Commerce v. United States, 224 Fed. 679, 681 (9th Cir. 1915), cert. denied, 241 U.S. 658 (1916) ; Security First Nat'1 Bank v. United States, 103 F.2d 188, 189 (9th Cir. 1939) (dictum) (Veterans' Bureau has no authority to issue checks payable to fictitious or non-existent persons). See 31 C.F.R. $\$ 208.4$ (1949). This governmental denial reinforces the conclusion that the government would not intend to make checks payable to fictitious payees.

43. United States v. National Bank of Commerce, 205 Fed. 433, 437 (9th Cir. 1913).

44. Id. at 438 .

Allowing the government to recover in this case appears to violate established principles of federal law as well. The employee who actually drew the check either did or did not have authority to do so. If he had authority, his knowledge and intent would have been imputed to the government as the court itself recognized. Ibid. With his intent so imputed, the check would be payable to bearer, and the government could not recover. On the other hand, if the employee did not have authority, his signing the check would constitute forgery. See United States v. Chase Nat'l Bank, 252 U.S. 485, $492-93$ (1920). Although the employee's subsequent endorsement would be another forgery, the government would still be barred from recovery under the final payment rule. The forged endorsement does not affect the government's failure as drawee to detect the forged drawer's signature. United States v. Chase Nat'l Bank, supra at 495-96.

45. See note 51 infra and accompanying text.

46. See National Metropolitan Bank v. United States, 323 U.S. 454, 458-59 (1945); Washington Loan \& Trust Co. v. United States, 134 F.2d 59, 62 (D.C. Cir. 1943). 
breach of its freely made guaranty. ${ }^{47}$ Only negligence proximately affecting the conduct of a bank in guaranteeing endorsements will bar recovery by the government. ${ }^{48}$

Disregarding the government's negligence undermines a basic objective of commercial law through inhibiting the promotion of sound business practice. By imposing risk of loss on those who fail to meet a reasonable standard of care, the commercial law induces adherence to such practice. ${ }^{49}$ The aim is achieved when the impostor rule bars recovery by the government because of the lack of care with which it issued a check. ${ }^{50}$ And utilization of the fictitious payee rule would further implement this end. The government has the best opportunity to avoid any loss that may result from the acts of a fraudulent employee. It can make extensive character investigations of those it hires, safeguard the disbursing process by audit and control, and require fidelity bonds from its employees. ${ }^{51}$ Recognizing negligence as ground for denying recovery by the government would stimulate it to take appropriate steps in an effort to minimize potential losses.52

Accordingly, federal courts should adopt the fictitious payee rule and give full scope to the impostor rule. The fictitious payee rule should apply when the fraudulent employee has the questioned check signed by another as well as when he signs it himself. ${ }^{53}$ Secondly, cases of checks delivered to the right name but the wrong person and those involving endorsement by the impostor's accomplice should be recognized as within the compass of the impostor rule..$^{54}$ Since misplaced trust and failure to exercise proper supervision are common to all of these situations, allowing the rules to bar governmental recovery effectuates recognition of negligence as the basis of liability. ${ }^{55}$ Adoption of these

47. National Metropolitan Bank v. United States, supra note 46, at 458. Considering a guaranty required on presentment for payment as freely made appears questionable. See note 15 supra and accompanying text. See also Brief for Appellees, p. 43, National Metropolitan Bank v. United States, supra, (Treasury Department practice to decline to pay checks presented without guaranty of prior endorsements).

48. See United States v. National Exchange Bank, 214 U.S. 302, 319 (1909) (dictum).

49. See, c.g., Uniforar Commerclas Code $\$ 3-406$; Corker, Risk of Loss from Forged Indorscmonts, 4 STAN. L. REv. 24, 27-28 (1951); Britton, Negligence in The Law of Bills and Notes, 24 Colum. L. Rev. 695 (1924); Notes, 54 MiCH. L. Rev. 996 (1956), 96 U. PA. L. Rev. 134 (1947), 27 VA. L. Rev. 103 (1940).

50. See note 27 supra.

51. Corker, supra note 49, at 31-32; Moore, Forgery by Employees, 3 The Practical Lawyer No. 1, p. 60 (Jan. 1957); Comment, 18 U. ChI. L. Rev. 281, 288 (1951).

52. If the government is not held liable in both impostor and fictitious payee cases, it will not be induced to introduce a program designed to prevent the occurrence of these cases. If, on the other hand, the government is held liable, it will introduce such a program whenever the cost is less than the losses otherwise resulting. Moreover, the government, through its control over the persons issuing these checks, is the only party that could introduce a successful program and thus be able to compare the cost of prevention with the cost of non-prevention.

53. See notes 33, 36-37 supra and accompanying text.

54. See notes 30,31 supra and accompanying text.

55. Absent gross negligence on the part of the government, lack of care by any other party should relieve it from liability. State courts have occasionally employed such a com- 
changes would result in the government's bearing the risk of loss from forged check transactions at least as often as private parties.

But the unique position of the government as a risk-distributor justifies its bearing the risk of loss where private parties would not be liable. ${ }^{56}$ This result flows from extension of the final payment rule to all forgery situations. ${ }^{57}$ Thus, the government would be presumed to know the signatures of its payees and payment on a forged endorsement would be deemed adoption of the check as valid. ${ }^{58}$ Admittedly, the possibility of the government's actually knowing the signatures of its payees appears slight. But actual knowledge of the amount of a check or of the signature of a drawer seems equally improbable. Yet the government is regularly held to the latter under the final payment rule. ${ }^{50}$ The ultimate justification for governmental liability under this rule lies in considerations of risk distribution. Still, whether the particular loss was caused by forgery of a drawer's signature, an improper endorsement or a raised amount, the government has similar likelihood of knowledge and equal capacity for risk distribution. In the absence of another party's negligence, therefore, it should consistently bear the risk of loss.

Extension of the final payment rule, as modified by negligence concepts, will place the loss on the best risk-distributor, promote transferability of government checks and contribute to a reduction in forgeries. Even if the government never bore the loss under existing law and would always do so with the doctrine revised, the resulting increase in government expenditures would be negligible. ${ }^{60}$ But bearing the loss from a forged check would generally be a

parative negligence standard in fixing liability. See, e.g., Basch v. Bank of America Nat'1 Trust \& Sav. Ass'n, 22 Cal. 2d 316, 139 P.2d 1 (1943). For a discussion of the problems involved in establishing a standard of reasonable care in commercial transactions, see Klaus, Identification of the Holder and Tender of Receipt on The Counter-Presentation of Checks, 13 Minn. L. Rev. 281 (1929); Comment, 62 YaLE L.J. 417, $438-39$ (1953).

56. Placing the loss from check forgeries on the best risk-distributor has been recommended by several commentators. See, e.g., Corker, supra note 49, at 30-31; Kessler, Forged Indorsements, 47 Yale L.J. 863, 896-97 (1938) ; Notes, 43 ILL. L. REv. 823, 831 (1949), 37 Minn. L. Rev. 201, 204 (1953), 14 U. CHI. L. Rev. 705, 708 (1947).

57. See text at notes 8-11 supra.

58. See notes 9, 11 supra and accompanying text.

The government is not charged with knowledge of the signatures of its payees under existing law. Clearfield Trust Co. v. United States, 318 U.S. 363, 369 (1943) ; United States v. National Exchange Bank, 214 U.S. 302, 317-18 (1909) (discussion of policy).

Uniess the government was presumed to know the signatures of its endorsers as well as those of its payees, the taker from the forger would bear the ultimate risk of loss when an endorser's signature was forged. See note 5 supra and accompanying text. But this possibility is slight. No case has been found in which an endorser's signature was forged.

59. See notes 9, 11 supra and accompanying text.

60. Total government expenditures for fiscal year 1955 were over sixty-four billion dollars. Sec'y Treas. ANN. Rep. 383 (1956). And the total loss from forged checks was over two and one-half million dollars. See note 1 supra. Therefore, assuming the government bore the entire forgery loss and had borne none of it previously, the resulting increase in the budget would be approximately $.0004 \%$, an annual per capita charge of less than one and one-half cents.

The government presently discharges its losses from forged checks with funds appropriated for that specific purpose. 55 STAT. 777 (1941), 31 U.S.C. $\$ 561$ (1952). 
burden on any other party. ${ }^{61}$ Moreover, should the loss ultimately rest on a good risk-distributor, such as a bank, its capacity to spread losses could not approach that of the government which has the taxing power at its disposal. ${ }^{62}$ This contrast is accentuated when the loss is borne by a party unlikely to insure and without ability to distribute the risk by other means. ${ }^{63}$ Extending the final payment rule will also increase transferability since private parties, protected from forgery loss, will be more willing to accept government checks. ${ }^{64}$ And realizing that their negligence will shift the risk of loss from the government to themselves, private parties will, like the government, be stimulated to employ better business practice in order to minimize potential losses. With all parties thus seeking to prevent loss, the possibilities for successful forgery should be substantially restricted.

61. See note 63 infra.

62. A bank can satisfactorily cover its forgery losses by insurance. See Comment, 62 YALE L.J. 417, 435-37 (1953). And it can spread the cost of the insurance to its customers by charging higher rates for checking services. Its ability to do this, however, is limited by the willingness of its competitors to charge similar fees and by the degree of substitutability between checks and other methods of payment.

63. And this is the typical result since the "original taker" from the forger is usually a small merchant who lacks ability to spread his losses. See Corker, supra note 49 , at 31 ; Comment, 62 Yale L.J. 417, 433 n. 112 (1953).

64. See, e.g., United States v. First Nat'l Bank, 131 F.2d 985, 989 (10th Cir. 1942), cert. denicd, 318 U.S. 774 (1943) (application of impostor rule to government checks to promote transferability) ; United States v. Peoples-Pittsburgh Trust Co., 34 F. Supp. 230 (W.D. Pa. 1940) (restriction on guaranty of prior endorsements); Note, 54 MICH. L. REv. 996 (1956). 